\title{
Kommende DUDS kurser
}

- 11. juni 2014 Basalkursus i Dopplerultralyd, DUDS. Kurset afholdes hos GE Healthcare, Brøndby

- 1. - 3. september 2014 DUDS Basiskursus i Ultralyd, Herlev Hospital

- 9. september 2014 Klinisk ultralyd (praksis)lægens nye værktøj, CEKU, Rigshospitalet

- 12. september 2014 31. Intro-kursus i akut abdominal ultralydskanning inkl. FAST og E-FAST skanning, Rigshospitalet
- 27. oktober 2014 Klinisk ultralyd (praksis)lægens nye værktøj, CEKU, Rigshospitalet

- 5. - 7. november 2014 DUDS‘ 18. kursus i muskuloskeletal ultralyd, Hvidovre Hospital

- 7. november 2014 Basalkursus i ultralydskanning af bevægeapparatet, CEKU, Rigshospitalet

- 28. november 2014 Klinisk ultralyd (praksis)lægens nye værktøj, CEKU, Rigshospitalet

Yderligere oplysninger om kurser, inklusive programmer, kan ses på www.duds.dk 